\title{
Neuromodulatory Effects of Gonadotropin Releasing Hormone on Olfactory Receptor Neurons
}

\author{
Heather L. Eisthen, ${ }^{1}$ Rona J. Delay, ${ }^{1}$ Celeste R. Wirsig-Wiechmann, ${ }^{2}$ and Vincent E. Dionne ${ }^{1}$ \\ ${ }^{1}$ Boston University Marine Program, Marine Biological Laboratory, Woods Hole, Massachusetts 02543, and ${ }^{2}$ Department \\ of Anatomy and Neurobiology, Boston University School of Medicine, Boston, Massachusetts 02118
}

The terminal nerve is an anterior cranial nerve that innervates the lamina propria of the chemosensory epithelia of the nasal cavity. The function of the terminal nerve is ambiguous, but it has been suggested to serve a neuromodulatory role. We tested this hypothesis by exposing olfactory receptor neurons from mudpuppies (Necturus maculosus) to a peptide, gonadotropin releasing hormone $(\mathrm{GnRH})$, that is found in cells and fibers of the terminal nerve. We used voltage-clamped wholecell recordings to examine the effects of $0.5-50 \mu \mathrm{m} \mathrm{GnRH}$ on voltage-activated currents in olfactory receptor neurons from epithelial slices. We found that $\mathrm{GnRH}$ increases the magnitude, but does not alter the kinetics, of a tetrodotoxin-sensitive inward current. This increase in magnitude generally begins 5-10 min after initial exposure to $\mathrm{GnRH}$, is sustained for at least 60 min during $\mathrm{GnRH}$ exposure, and recovers to baseline within 5 min after $\mathrm{GnRH}$ is washed off. This effect occurred in almost $60 \%$ of the total number of olfactory receptor neurons examined and appeared to be seasonal: $\sim 67 \%$ of neurons responded to $\mathrm{GnRH}$ during the courtship and mating season, compared with $\sim 33 \%$ during the summer, when the sexes separate. $\mathrm{GnRH}$ also appears to alter an outward current in the same cells. Taken together, these data suggest that $\mathrm{GnRH}$ increases the excitability of olfactory receptor neurons and that the terminal nerve functions to modulate the odorant sensitivity of olfactory receptor neurons.

Key words: amphibian; GnRH; modulation; mudpuppy; Necturus; nervus terminalis; olfaction; peptide; salamander; sodium current; terminal nerve
The terminal nerve is an anterior cranial nerve first described in the late 1800s (Fritsch, 1878; Pinkus, 1894, 1895). The fibers of the terminal nerve extend posteriorly to the hypothalamic/ preoptic area and anteriorly to the nasal cavity; in teleost fishes, a branch extends to the retina (Demski, 1993). The cell bodies of the terminal nerve are located in a ganglion or series of ganglia along the olfactory nerve, olfactory bulb, or basal forebrain. The histochemistry of the terminal nerve has not been fully characterized in a single species, but in most jawed vertebrates the terminal nerve contains gonadotropin releasing hormone (GnRH) and shows FMRFamide-like immunoreactivity (Eisthen and Northcutt, 1996). In addition, the terminal nerve of some animals contains acetylcholine (Schwanzel-Fukuda et al., 1986; Wirsig and Leonard, 1986; Wirsig-Wiechmann, 1990; White and Meredith, 1995), tyrosine hydroxylase (White and Meredith, 1995), and/or neuropeptide Y (Chiba and Honma, 1992; Vallarino et al., 1995).

The function of the terminal nerve is unknown. Anatomical considerations have led several authors to suggest that the nerve is sensory (Rossi et al., 1972; Demski and Northcutt, 1983). However, electrophysiological recordings from the terminal nerve

Received Sept. 29, 1999; revised March 2, 2000; accepted March 14, 2000.

This work was supported by the following awards: National Institutes of Health Grants R03DC02879 (H.L.E.), F32DC00176 (R.J.D.), and R01DC00256 (V.E.D.), and National Science Foundation Grant IBN 9496258 (C.R.W-W.). We thank Tim Day, Kathleen Dorries, and Edward Siuda for advice and constructive comments on this manuscript.

Correspondence should be addressed to Heather L. Eisthen at her current address: Department of Zoology, Michigan State University, 203 Natural Sciences Building, East Lansing, MI 48824-1115. E-mail: eisthen@msu.edu.

Dr. Delay's current address: Department of Biology, University of Vermont, Burlington, VT 05405.

Dr. Wirsig-Wiechmann's current address: Department of Cell Biology, University of Oklahoma Health Sciences Center, Oklahoma City, OK 73190.

Copyright (C) 2000 Society for Neuroscience $0270-6474 / 00 / 203947-09 \$ 15.00 / 0$ have failed to detect clear sensory responses (Bullock and Northcutt, 1984; Fujita et al., 1991; White and Meredith, 1995). Behavioral experiments that controlled for nonspecific damage indicate that terminal nerve lesions impair some, but not all, aspects of mating behavior in male hamsters (Wirsig and Leonard, 1987; Wirsig-Wiechmann, 1993a) but do not demonstrate that the nerve is sensory.

An alternate hypothesis suggests that the terminal nerve serves a neuromodulatory function. The cell bodies possess undifferentiated processes (Wirsig-Wiechmann, 1993b) and contain compounds that can act as neuromodulators, including GnRH. Binding studies of GnRH agonists indicate that the olfactory epithelium of tiger salamanders contains $\mathrm{GnRH}$ receptors (Wirsig-Wiechmann and Jennes, 1993), suggesting that compounds released from the terminal nerve may affect activity of olfactory receptor cells. In goldfish, application of $\mathrm{GnRH}$, FMRFamide, and other compounds present in the terminal nerve alters the activity of retinal ganglion cells (Walker and Stell, 1986), suggesting that the retinopetal branch of the terminal nerve in teleosts may be neuromodulatory. The projection to the olfactory epithelium may play a similar role in a wide range of vertebrates, although the stimulus for peptide release from the terminal nerve is unclear. Recordings from the cell bodies of the terminal nerve demonstrate that the cells are tonically active (Fujita et al., 1991) and that the majority fire spontaneous action potentials at a constant frequency (Oka and Matsushima, 1993). Extracellular recordings indicate that the terminal nerve also carries efferent impulses that suppress activity of the terminal nerve cells (Bullock and Northcutt, 1984; White and Meredith, 1987), as does tactile stimulation of the body (Fujita et al., 1991).

We verified that the terminal nerve of an aquatic salamander, the mudpuppy, is immunoreactive for $\mathrm{GnRH}$, and then examined 


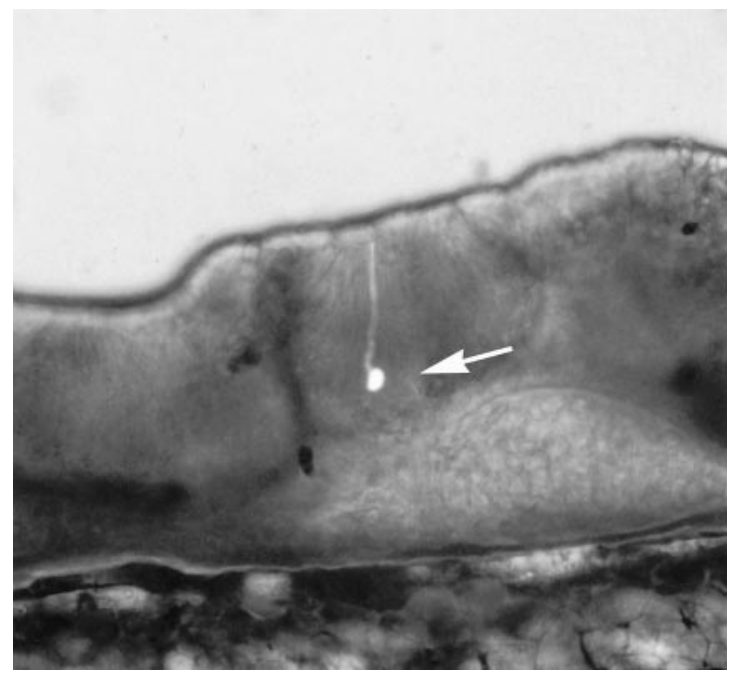

Figure 1. Photomicrograph of a slice, 200-250 $\mu \mathrm{m}$ thick, of mudpuppy olfactory epithelium, photographed with a combination of epifluorescence and bright-field illumination with differential interference contrast. Whole-cell patch-clamp recordings were made from the olfactory receptor neuron indicated by the arrow. Lucifer yellow was added to the recording pipette to facilitate examination of the morphological characteristics of the neuron.

the effects of GnRH on the olfactory receptor cells. We found that GnRH increases the magnitude of a voltage-activated, tetrodotoxin (TTX)-sensitive inward current and may alter an outward current as well. These data constitute the first demonstration that peptides found in the terminal nerve modulate activity of olfactory receptor cells.

\section{MATERIALS AND METHODS}

Subjects. Healthy adult mudpuppies (Necturus maculosus) of both sexes were used as subjects in all experiments. Mudpuppies were obtained from licensed suppliers (Kons Scientific Co., Germantown, WI, and William A. Lemberger Co., Oshkosh, WI) and maintained in small groups in aquaria at $\sim 20^{\circ} \mathrm{C}$.

All procedures were conducted under the supervision of the institutional animal care and use committees from Boston University and the Marine Biological Laboratory, in accordance with guidelines established by the Public Health Service and the Society for Neuroscience.

Immunohistochemistry. Because the distribution of $\mathrm{GnRH}-$ immunoreactive fibers has not been described in mudpuppies, we verified that mudpuppies possess GnRH-immunoreactive terminal nerve fibers that extend to the olfactory epithelium before conducting studies of the effects of GnRH on olfactory receptor cells.

Three mudpuppies were used as subjects in this study. Animals were deeply anesthetized by immersion in $1 \%$ tricaine methanesulfonate (MS222, Sigma-Aldrich, St. Louis, MO). Animals were transcardially perfused with $10 \mathrm{ml}$ saline followed by $120 \mathrm{ml}$ Zamboni's fixative at a rate of $5 \mathrm{ml} / \mathrm{min}$. The head was removed, decalcified whole in DeCal (Decal Chemical, Congers, NY) for $3 \mathrm{~d}$, and cryoprotected in $30 \%$ sucrose. Serial horizontal sections were cut on a cryostat at $30 \mu \mathrm{m}$ and stored at $-20^{\circ} \mathrm{C}$ until they were processed following standard immunohistochemical protocols.

Sections were preincubated in a blocking solution containing $0.2 \%$ Triton X-100 and 1\% normal goat serum in PBS, pH 7.4. Sections were then incubated with the primary antibody (anti-LHRH, DiaSorin, Stillwater, $\mathrm{MN}$ ) diluted 1:4000 in blocking solution for $3 \mathrm{~d}$, rinsed with PBS between 30 min incubations in goat anti-rabbit secondary antibody and HRP-avidin (Vector Laboratories, Burlingame, CA), then reacted with diaminobenzidine and counterstained with methyl green.

Physiological recordings. We used 36 healthy adult mudpuppies of both sexes as subjects for physiological experiments. Whole-cell recordings were made from individual olfactory receptor neurons in epithelial slices, as illustrated in Figure 1. The slice preparation has significant advantages over the more common isolated-cell preparations: the receptor cells retain their intercellular connections; the method does not expose the receptor cells to enzymes or harsh osmotic treatments, which can interfere with odorant responsivity; and cells in slices remain viable up to $48 \mathrm{hr}$.

Epithelial slices were prepared using a protocol modified from that described by Bigiani and Roper (1995). Mudpuppies were immersed in ice water for $20 \mathrm{~min}$ and then decapitated. The nasal sac was dissected out of its capsule, slit longitudinally, opened flat, and attached to a support with cyanoacrylate glue. Slices $200-250 \mu \mathrm{m}$ thick were cut with a vibrating blade and stored in amphibian physiological saline containing (in $\mathrm{mM}$ ): $120 \mathrm{NaCl}, 10 \mathrm{HEPES}, 8 \mathrm{CaCl}_{2}, 5$ glucose, 5 pyruvate, $2.5 \mathrm{KCl}$, and $1 \mathrm{MgCl}_{2}$. Slices of olfactory epithelium prepared in this manner remained viable for recording at room temperature for at least $4 \mathrm{hr}$, and when stored at $4^{\circ} \mathrm{C}$ could be used for $48 \mathrm{hr}$.

Epithelial slices were mounted in a recording chamber and viewed with a $40 \times$ water immersion objective (total magnification $400-500 \times$ ) on a Zeiss Axioskop FS microscope equipped with DIC optics. Patch electrodes of borosilicate glass were pulled on a Flaming-Brown programmable micropipette puller (Sutter Instruments, Novato, CA) and coated with wax to reduce electrode capacitance. For whole-cell voltage-clamp recordings, pipette resistance was generally $3-5 \mathrm{M} \Omega$. All recordings were conducted at room temperature using an Axopatch 1B amplifier (Axon Instruments, Foster City, CA) with a low-pass Bessel filter set at 5-10 $\mathrm{kHz}$. Raw data were collected and leak current was subtracted before analysis using software developed in the laboratory.

For experiments that did not require the use of ionic substitutions or ion channel blockers in the intracellular solution, the recording pipette was filled with a solution containing (in $\mathrm{mM}$ ): $105 \mathrm{~K}$ gluconate, $25 \mathrm{KCl}$, $10 \mathrm{HEPES}, 5$ ATP, $3 \mathrm{MgSO}_{4}, 1 \mathrm{~K}_{4}$ BAPTA or EGTA, $0.5 \mathrm{GTP}$, and 0.5 $\mathrm{CaCl}_{2}$. In most experiments, cesium was substituted for potassium to block large outward currents that might mask GnRH-sensitive inward currents. In these experiments, the intracellular solution contained (in mM): $130 \mathrm{CsCl}, 10 \mathrm{HEPES}, 5 \mathrm{ATP}, 3 \mathrm{MgSO}_{4}, 1 \mathrm{~K}_{4}$ BAPTA, 0.5 GTP, and $0.085 \mathrm{CaCl}_{2}$, and calcium-dependent outward currents were also blocked through the substitution of $\mathrm{BaCl}_{2}$ for $\mathrm{CaCl}_{2}$ in the amphibian physiological saline described above.

The effects of $\mathrm{GnRH}$ on olfactory receptor cells were examined using the mammalian form of $\mathrm{GnRH}$, which is the form present in the terminal nerve of amphibians (Sherwood et al., 1986; Iela et al., 1996). Mammalian GnRH (Peninsula Labs, Belmont, CA) was dissolved in amphibian physiological solution at concentrations ranging from 0.5 to $50 \mu \mathrm{M}$ and bath-applied to slice preparations during recording. We added a dye, fast green, to this solution to allow us to verify the timing of GnRH application and wash. Bath solutions were introduced into the recording chamber using a gravity-feed system. Our observations indicate that the bath solution covering a slice was completely replaced 30-60 sec after solution sources were changed.

For each recording, we followed a standard protocol to ensure that comparable data were collected from all cells. Specifically, once a seal of 3-5 G $\Omega$ was attained, the membrane under the electrode was ruptured, and a holding potential of either -70 or $-90 \mathrm{mV}$ was applied to maximize the inward current. We then recorded responses to a series of voltage pulses generally ranging from $-80 \mathrm{mV}$ to $100 \mathrm{mV}$ in $10 \mathrm{mV}$ steps. We then initiated the flow of bath solution over the slice and recorded responses to a similar set of pulses 1 min later. Recordings were made every $2.5 \mathrm{~min}$ in flowing bath until the seal and series resistance stabilized; for most cells, these variables were stable, and only two sets of recordings were made in the flowing bath before $\mathrm{GnRH}$ was applied. Recordings were made 1 min after the flow of GnRH was initiated, then again at $2.5 \mathrm{~min}$ intervals for $15-45 \mathrm{~min}$. For most cells, we waited 20-25 min before we began to wash off the GnRH with amphibian physiological saline. Recordings were made after $1 \mathrm{~min}$ of washing and then at $2.5 \mathrm{~min}$ intervals for $20-40 \mathrm{~min}$.

In some experiments, a bath solution containing fast green but not GnRH was used as a control for the effects of changing the solution or of washing fast green onto the slice. In the remainder of this article, we refer to this solution as the "control solution"; note that the control solution is different from the "wash," which consisted of plain physiological saline without fast green. In other experiments, the identity of the inward sodium current was verified through the application of $1 \mu \mathrm{M}$ TTX (Calbiochem, San Diego, CA) in the bath solution, either after 20 min of GnRH application or after washing to full recovery. We included $10 \mu \mathrm{M}$ GnRH in the TTX solution to ensure that the response obtained was caused by the TTX and not simply by washing off the GnRH solution.

In all experiments, once a slice had been exposed to any solution other than plain amphibian physiological saline, the slice was discarded and a 
fresh one used for the next recording. To examine the effects of varying the concentration of GnRH applied to a slice, we used the protocol described above to record from cells exposed to GnRH at $0.5,1,5,10$, and $50 \mu \mathrm{M}$. Because of the slow time-scale of the response to GnRH, we were not able to record responses to more than one concentration per cell. However, to control for possible differences attributable to such variables as time of year, sex or health of animals, room temperature, and preparation of solutions or glass recording pipettes, we recorded responses to different concentrations of GnRH from different cells from the same animal. For these experiments, the first cell was exposed to the control solution to establish a baseline for changes attributable to such factors as rundown. The next cell (from a different slice) was exposed to $10 \mu \mathrm{M} \mathrm{GnRH}$, to establish a standard of responding. In subsequent recordings from cells in other slices from the same animal, different concentrations of GnRH were applied and compared with the results obtained from the two recordings described above.

We included in our analyses only recordings in which GnRH or the control solution was applied to the epithelial slice for at least $15 \mathrm{~min}$, the measured series resistance did not vary by more than $10 \mathrm{M} \Omega$, and the seal was at least $1 \mathrm{G} \Omega$ throughout the recording. Using these criteria, we report data from a total of 72 cells that were subjected to various recording conditions and experimental protocols. In all cases, leak currents were subtracted before the data were displayed and analyzed. Statistical analyses were performed using the JMP software package (SAS Institute, Cary, NC). To avoid problems with pseudoreplication, no more than two cells from a single animal were included in a single group in our $t$ tests.

\section{RESULTS}

\section{Mudpuppies possess a GnRH-immunoreactive terminal nerve}

The peripheral distribution of the GnRH-immunoreactive terminal nerve was similar to that seen in other amphibian species, such as tiger salamanders (Wirsig-Wiechmann, 1993b), bullfrogs (Wirsig and Getchell, 1986), Xenopus (Wirsig-Wiechmann and Lee, 1999), and newts (Murakami et al., 1992). Peripherally, labeled fibers could be traced within the olfactory nerve to the lamina propria of the olfactory mucosa, where they terminated just deep to the olfactory epithelium, as illustrated in Figure 2. As is typical in many species, fiber labeling decreased peripherally along the olfactory nerve; that is, many fibers were observed in the olfactory nerve adjacent to the olfactory bulb, but very few were visible adjacent to the olfactory mucosa. Previous experiments indicate that this diminution in labeling is caused by the low levels of the peptide in the peripheral portion of the fibers, rather than a lack of fibers peripherally (Wirsig-Wiechmann, 1993b). Scattered GnRH-immunoreactive cell bodies were observed underneath the olfactory epithelium and throughout the olfactory nerve from the epithelium to the rostral edge of the olfactory bulb. In dorsal sections, GnRH-immunoreactive cells were clustered among a bundle of labeled fibers that penetrated the olfactory bulb and passed to the medial portion of the telencephalon, where the fibers proceeded caudally, presumably following the path of the terminal nerve.

\section{GnRH amplifies an inward current in olfactory receptor cells}

The most dramatic result of GnRH application was an increase in the magnitude of a large, rapidly inactivating inward current in the majority of cells, which we classified as "responders," as described below. In these cells, the magnitude of this current recovered to baseline levels when the GnRH was washed off, as illustrated in Figure 3. We did not observe any cases in which $\mathrm{GnRH}$ altered the rate of activation or timing of the peak of the inward current. We first observed the effect of GnRH on the magnitude of the inward current when $10 \mu \mathrm{M}$ GnRH was applied during recordings in which no blockers or ionic substitutions were

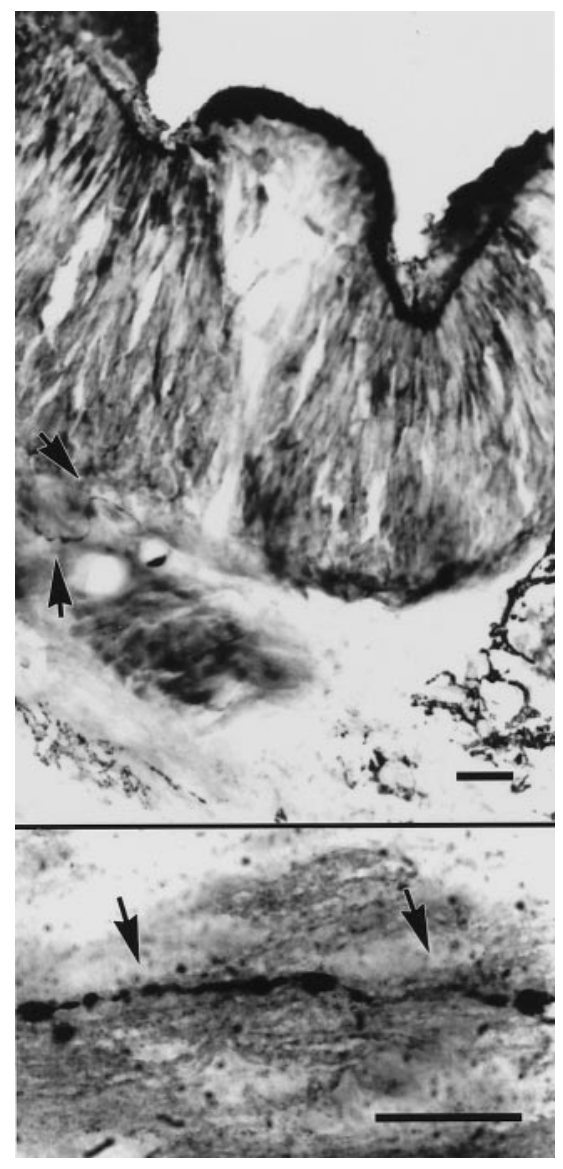

Figure 2. Photomicrographs of cross-sections through the nasal capsule of an adult mudpuppy, immunolabeled for GnRH and stained with methyl green. Top panel, Arrowheads indicate a fiber below the olfactory epithelium that has been labeled with antiserum to the mammalian form of GnRH. Bottom panel, A GnRH-immunoreactive fiber in the olfactory nerve of the same animal. Scale bars, $25 \mu \mathrm{m}$.

used, and we continued to use this concentration for most subsequent recordings.

We examined data for responses to $10 \mu \mathrm{M}$ GnRH from 49 cells from 23 different mudpuppies, using both quantitative and qualitative analyses. Our observations indicated that not all cells responded to $10 \mu \mathrm{M} \mathrm{GnRH}$ with an increase in the voltageactivated inward current. We categorized cells as "responders" or "nonresponders" based on the dynamics of inward current during the period of GnRH exposure. Cells were classified as responders if the inward current was elevated above baseline for at least five consecutive readings (10 $\mathrm{min}$ ) while exposed to GnRH. Cells were classified as nonresponders if the inward current was equal to or below baseline for at least 20 min while exposed to GnRH. Using these criteria, we were able to categorize 43 of 49 cells that were exposed to $10 \mu \mathrm{M} \mathrm{GnRH}$; in the remaining six cells, the inward current was variable or started to increase shortly before the GnRH was washed off the slice. We found that 29 of the 49 cells $(59 \%)$ responded to the application of $\mathrm{GnRH}$ with a sustained increase in the magnitude of the inward current, and 14 cells $(29 \%)$ were unambiguously classified as nonresponders. We did not observe any cases in which the inward current decreased with GnRH exposure and then recovered when the GnRH was washed off the slice.

The recorded magnitude of the inward current varied consid- 

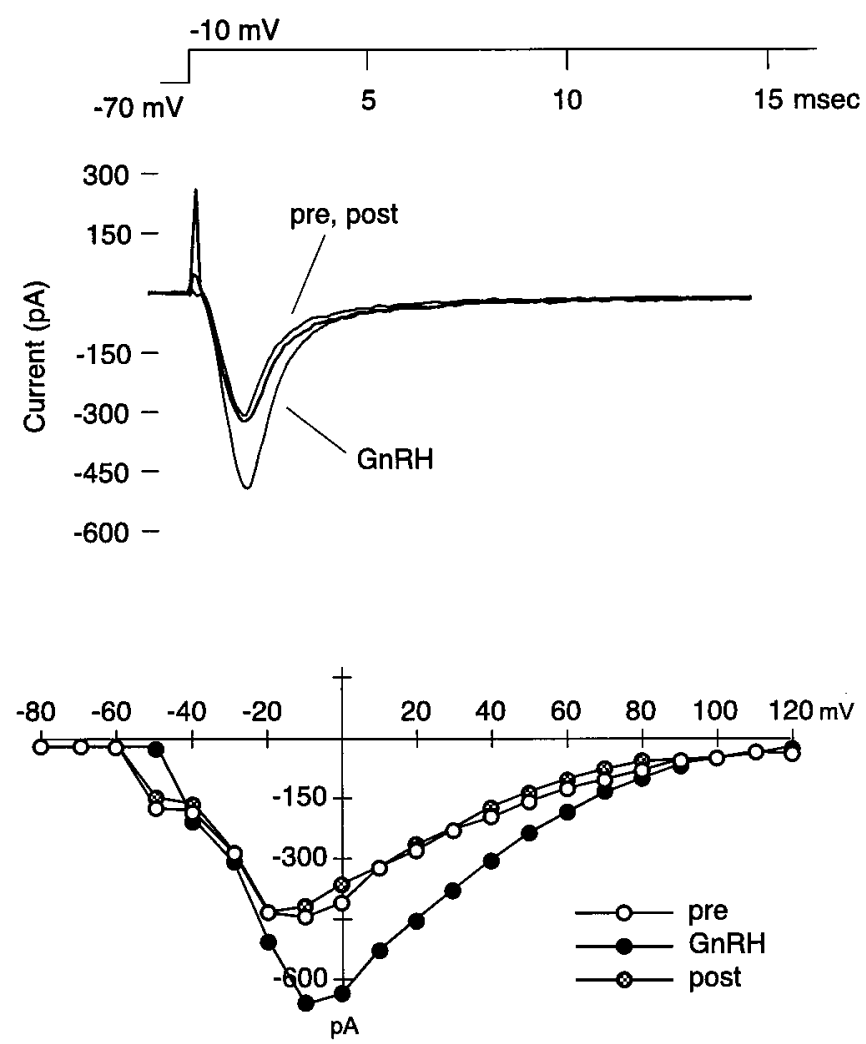

Figure 3. Whole-cell recordings from an olfactory receptor cell, illustrating an effect of bath application of $10 \mu \mathrm{M}$ GnRH. Outward currents have been blocked. $V_{\text {hold }}=-70 \mathrm{mV}$. Top panel, Inward currents elicited by a voltage pulse of $-10 \mathrm{mV}$, showing the magnitude of the inward current before application of GnRH (pre), after $20 \mathrm{~min}$ exposure to GnRH (GnRH), and after washing GnRH off the slice for 15 min (post). Bottom panel, Relationship between peak current and voltage for the same cell, at the same time points. Currents were elicited by application of a series of voltage pulses ranging from $-80 \mathrm{mV}$ to $+120 \mathrm{mV}$, in $10 \mathrm{mV}$ increments.

erably among cells, ranging from $\sim 400 \mathrm{pA}$ to $>2800 \mathrm{pA}$ in different cells. For purposes of statistical analysis and data display, we normalized all data to the magnitude of the inward current measured 1 min after starting to apply $\mathrm{GnRH}$ to the slice; although the values are not substantially different from those recorded immediately before the GnRH was applied, this time point was selected to minimize possible differences caused by changes in flow rate. To facilitate comparisons, we analyzed data from 25 cells from 14 different animals from which recordings were made with $\mathrm{CsCl}$ intracellular solution in the recording pipette and $\mathrm{BaCl}_{2}$ in the bath solution. These analyses included all cells from which we obtained good recordings, regardless of their assignment to the categories described above.

In general, the inward current began to increase in magnitude 5-10 min after GnRH was first washed onto the slice. Although the difference in magnitude of the inward current in cells exposed to GnRH or the control solution is not significant after 5 min of exposure, by $10 \mathrm{~min}$ after $\mathrm{GnRH}$ was first applied, the inward current was significantly larger in responsive cells relative to cells exposed to the control solution $\left(t_{(17)}=2.16, p<0.05\right)$. The inward current typically continued to increase in magnitude over the first $15 \mathrm{~min}$ of $\mathrm{GnRH}$ exposure and remained elevated throughout the duration of GnRH exposure. Nevertheless, we observed considerable variability in the time course of the re-

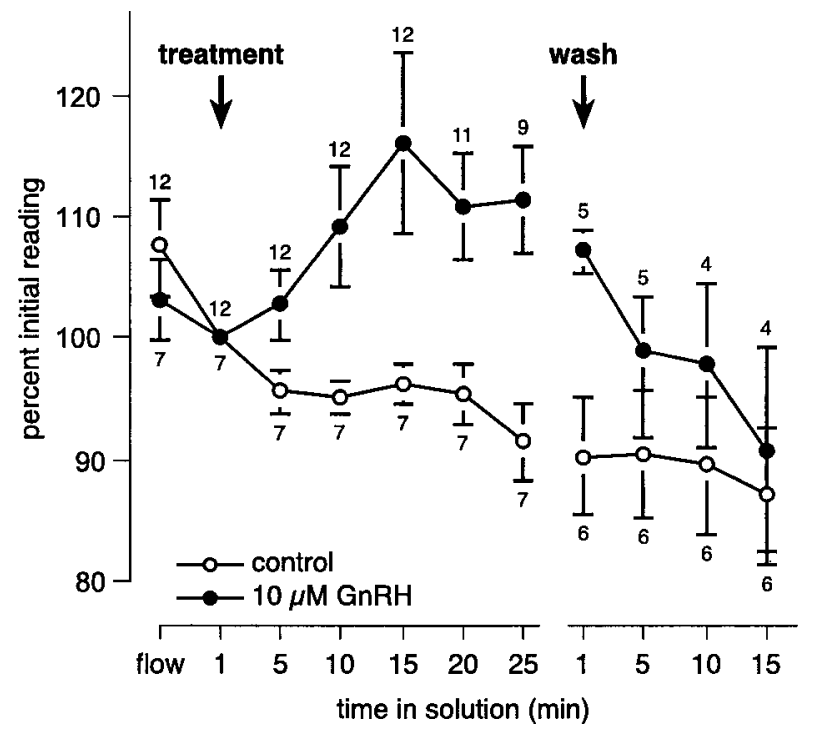

Figure 4. Change, over time, in the magnitude of the inward current. To facilitate comparison, data were normalized such that the magnitude of the inward current immediately after application of the test solution was designated $100 \%$, and the magnitude of the current at other times is expressed as a percentage of the magnitude at this time point. The arrow labeled treatment indicates the time at which $10 \mu \mathrm{M} \mathrm{GnRH}$ or the control solution was washed onto the slice and maintained for at least $25 \mathrm{~min}$; the solution was then washed off (wash). Means and SEs are shown for cells that responded to $\mathrm{GnRH}(\boldsymbol{)})$ or were exposed to a control solution containing an indicator dye but no $\mathrm{GnRH}(\mathrm{O})$. After $10 \mathrm{~min}$ in $\mathrm{GnRH}$, the magnitude of the inward current was significantly larger in cells responding to $\mathrm{GnRH}$ than in cells exposed to the control solution; within $5 \mathrm{~min}$ in wash, the magnitude of the inward current was indistinguishable in the two groups. In both groups, the inward current ran down to $\sim 86 \%$ of its original value by the end of the experiment. Some recordings were abandoned before the experiment ended if the cell died or the seal was lost, and the numbers above and below data points indicate the number of cells included in the analysis for each group at each time point. All recordings were made with $\mathrm{CsCl}$ in the intracellular solution and $\mathrm{BaCl}_{2}$ in the extracellular solution.

sponse to GnRH. Of the 29 cells that we classified as responders, the magnitude of the inward current continued to increase during the entire period of GnRH exposure, which ranged from 15 to 30 min, for 12 cells. In six cells, the magnitude of the inward current increased in the presence of GnRH and reached a stable level after 10-15 min of exposure, but in three cells an increase in the inward current was not apparent until 15-30 min after GnRH was first applied to the slice. In eight cells the magnitude of the inward current peaked after 10-20 min of exposure and then began to decline. The magnitude of the inward current remained significantly larger in responsive cells compared with controls immediately after the slice was exposed to the physiological saline used to wash off the GnRH $\left(t_{(9)}=3.07, p<0.02\right)$, indicating that changing the bath solution did not alter activity of the cells; however, after $5 \mathrm{~min}$ of washing, the magnitude of the inward current in GnRH-responsive cells returned to a level comparable to that of controls $\left(t_{(9)}=1.22, p>0.25\right)$. Among responsive cells, the inward current was an average of $12 \%$ larger than baseline during the period from $10 \mathrm{~min}$ of exposure until the GnRH was washed off; during this same time period, the inward current declined an average of $5.4 \%$ in cells exposed to the control solution. Figure 4 illustrates the time course and magnitude of the response to GnRH among cells categorized as responders, compared with controls. 


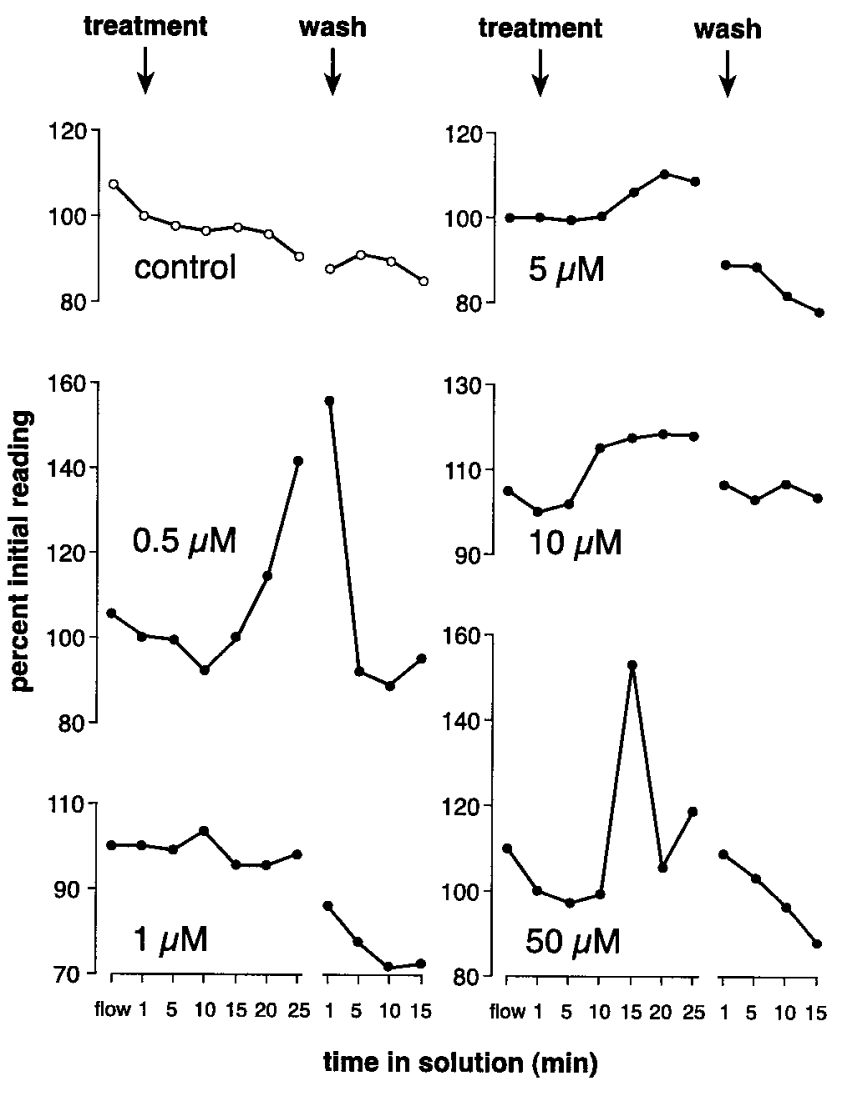

Figure 5. Change, over time, in the magnitude of the inward current, illustrating that olfactory receptor cells respond similarly to $\mathrm{GnRH}$ at concentrations ranging from 0.5 to $50 \mu \mathrm{M}$. The arrow labeled treatment indicates the time at which GnRH or the control solution was washed onto the slice; the solution was washed off at least 25 min later (wash). Means are shown for five cells exposed to a control solution that did not contain $\mathrm{GnRH}$, one cell that responded to $0.5 \mu \mathrm{M} \mathrm{GnRH}$, three cells that responded to $1 \mu \mathrm{M} \mathrm{GnRH}$, three cells that responded to $5 \mu \mathrm{M} \mathrm{GnRH}$, four cells that responded to $10 \mu \mathrm{M} \mathrm{GnRH}$, and two cells that responded to 50 $\mu \mathrm{M}$ GnRH. Note that the apparent late decrease in magnitude of the inward current in $50 \mu \mathrm{M} \mathrm{GnRH}$ is caused by the loss of one of the two cells; thus, after $15 \mathrm{~min}$ in $\mathrm{GnRH}$, the graph depicts data from only one cell. Data for responses to the control solution and $10 \mu \mathrm{M} \mathrm{GnRH}$ are from the same animals used to test the other concentrations shown in the Figure. All recordings were made with $\mathrm{CsCl}$ in the intracellular solution and $\mathrm{BaCl}_{2}$ in the extracellular solution.

In addition to our recordings of responses to $10 \mu \mathrm{M} \mathrm{GnRH}$, we were able to obtain recordings of responses to different concentrations of GnRH from different cells in five animals. We found that the effects of GnRH are similar across the range of concentrations tested. Specifically, we found that two of two cells exposed to $50 \mu \mathrm{M}$ GnRH could be categorized as responders; three of four cells responded to $5 \mu \mathrm{M} \mathrm{GnRH}$; three of four cells responded to $1 \mu \mathrm{M} \mathrm{GnRH}$; and one cell that was exposed to 0.5 $\mu \mathrm{M}$ GnRH also showed an increase in the magnitude of the inward current. Among the animals used for these particular experiments, four of six cells responded to $10 \mu \mathrm{M}$ GnRH. The average change in the inward current for cells that responded to GnRH is shown in Figure 5.

\section{GnRH affects a TTX-sensitive current}

The voltage-activated inward current that increased in the presence of GnRH was large and rapidly inactivating and resembled a sodium current. To further characterize this current, we used
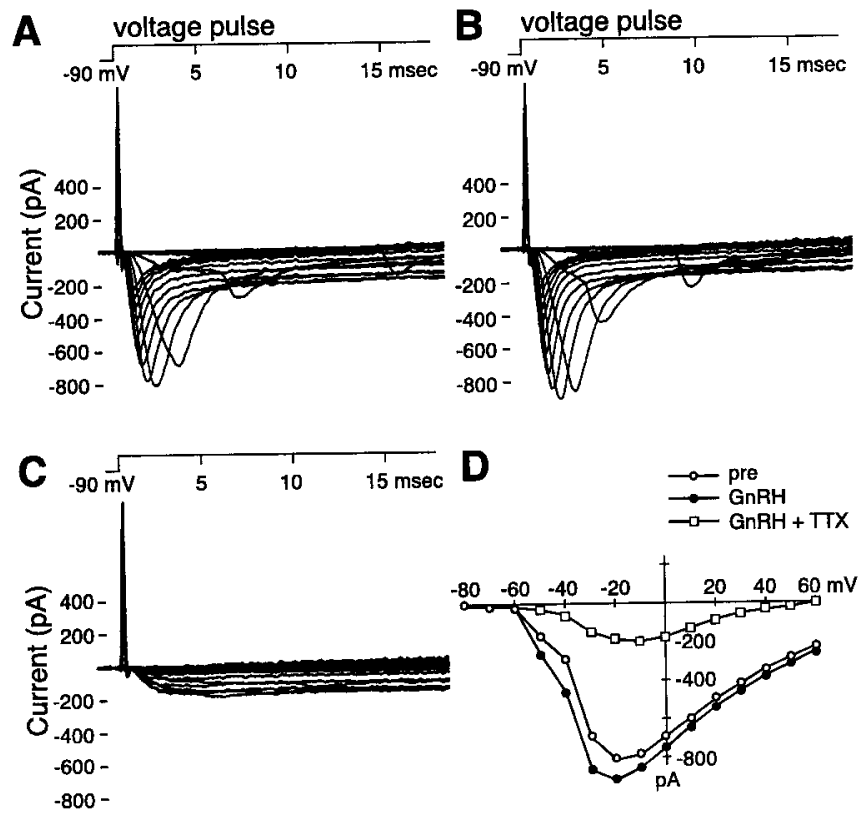

Figure 6. Whole-cell recordings from an olfactory receptor cell, illustrating the effect of tetrodotoxin $(T T X)$ on the inward current that is affected by $\mathrm{GnRH}$. This recording was made with $\mathrm{CsCl}$ in the intracellular solution and $\mathrm{BaCl}_{2}$ in the extracellular solution. $A$, Currents elicited by stepping from a holding potential of $-90 \mathrm{mV}$ to a series of voltage pulses ranging from $-80 \mathrm{mV}$ to $+60 \mathrm{mV}$, in $10 \mathrm{mV}$ increments. These currents were recorded immediately before $\mathrm{GnRH}$ was washed onto the slice. $B$, Currents elicited using the same protocol, after 25 min exposure to $10 \mu \mathrm{M} \mathrm{GnRH}$. The magnitude of the peak inward current is $\sim 11 \%$ larger than in $A$. $C$, Currents elicited using the same protocol, 3 min after a solution containing $10 \mu \mathrm{M}$ GnRH and $1 \mu \mathrm{M}$ TTX was washed onto the cell. This measurement was taken 4 min after that illustrated in $B$. Note that the large, rapidly inactivating, voltage-activated inward current that is probably carried by sodium has been blocked. A small, slowly inactivating current that is probably carried by barium is now apparent. $D$, Currentvoltage relationship for the sets of currents illustrated in $A-C$. The magnitudes of the initial currents are illustrated with open circles (pre), those recorded in the presence of GnRH are illustrated by closed circles $(G n R H)$, and those recorded in GnRH and TTX are illustrated by open squares $(\mathrm{GnRH}+\mathrm{TTX})$.

TTX in some recordings, as illustrated in Figure 6. For this experiment, we followed the standard recording protocol described above, with $\mathrm{CsCl}$-containing intracellular solution in the recording pipette and $\mathrm{BaCl}_{2}$ rather than $\mathrm{CaCl}_{2}$ in the bath solution. We measured the magnitude of voltage-activated currents every $2.5 \mathrm{~min}$ during $15-25 \mathrm{~min}$ of exposure to $10 \mu \mathrm{M}$ $\mathrm{GnRH}$, then replaced the bath with a solution containing $1 \mu \mathrm{M}$ TTX and $10 \mu \mathrm{M}$ GnRH.

The inward current that increased in magnitude in the presence of GnRH was abolished within 2-5 min of application of the TTX-GnRH solution in all seven cells from which we obtained good recordings. As shown in Figure 6, in some of these cells a different inward current persisted in the presence of TTX. This current is presumably carried by barium from the bath solution, because it resembles the calcium current that is typically present in mudpuppy olfactory neurons (Dionne, 1988). We were able to wash the TTX-GnRH solution off one cell and found that the inward current recovered to its baseline level within $\sim 15 \mathrm{~min}$.

\section{Other currents may also be affected by $\mathbf{G n R H}$}

The TTX-sensitive inward current may not be the only current that is affected by GnRH. We recorded from eight cells from six 

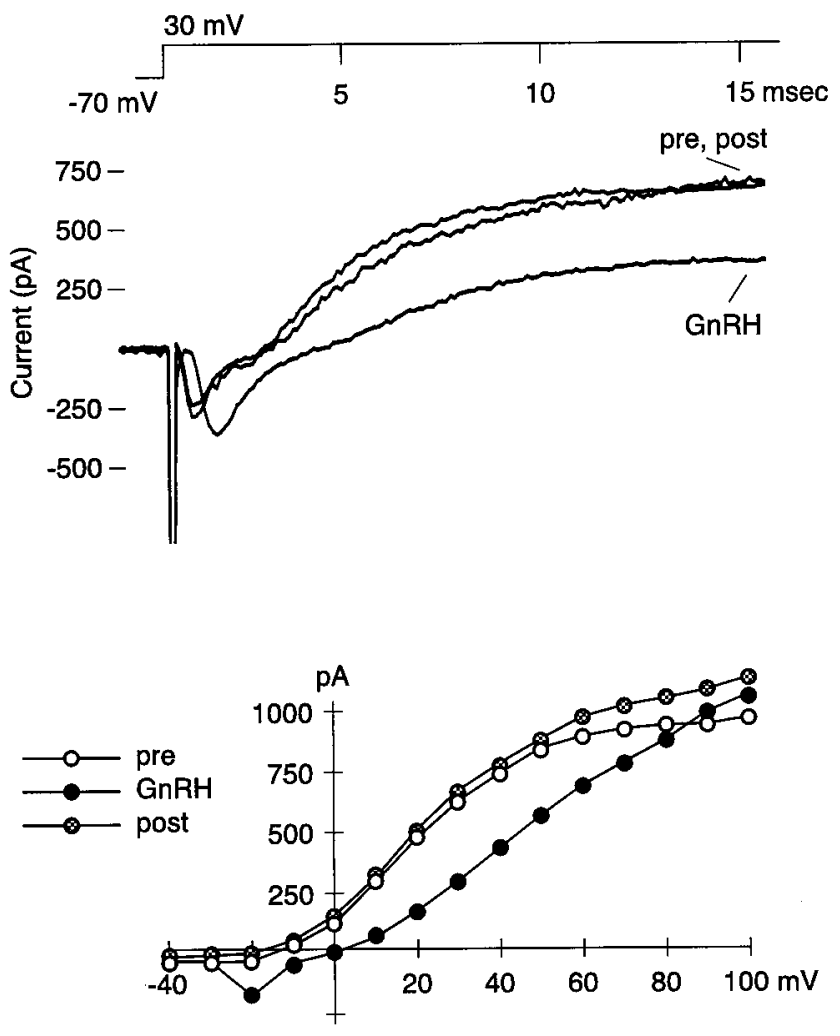

Figure 7. Whole-cell recordings from an olfactory receptor cell, illustrating a reduction in the outward current after bath application of $10 \mu \mathrm{M}$ GnRH. In these recordings, no channel blockers or ionic substitutions have been used. $V_{\text {hold }}=-70 \mathrm{mV}$. Top panel, Outward currents elicited by a voltage pulse of $+30 \mathrm{mV}$, showing the magnitude of the outward current before application of $\mathrm{GnRH}$ ( pre), after 12.5 min exposure to $\mathrm{GnRH}$ $(G n R H)$, and after washing GnRH off the slice for $12.5 \mathrm{~min}$ (post). Bottom panel, Relationship between peak current and voltage for the same cell, at the same time points. Currents were elicited by application of a series of voltage pulses ranging from $-80 \mathrm{mV}$ to $+100 \mathrm{mV}$, in $10 \mathrm{mV}$ increments. The graph is truncated below $-40 \mathrm{mV}$, because potentials more negative than $-40 \mathrm{mV}$ did not elicit outward currents.

different animals using standard intracellular and extracellular solutions that did not contain blockers or ionic substitutions. The results of one of these recordings are illustrated in Figure 7. In five of these eight cells, we found that the outward current was reduced at membrane potentials between roughly 0 and $+60 \mathrm{mV}$ after 5-10 min of exposure to $10 \mu \mathrm{M} \mathrm{GnRH}$. The current recovered to its original level 5-15 min after the GnRH was washed off the slice. We did not identify the current that was altered, although it resembles a calcium-dependent potassium current that is present in mudpuppy olfactory neurons (Dionne, 1988). In three of the five cells in which the outward current was altered, the magnitude of the inward current was also increased; this result was not obtained in any of the three cells in which no effect on the outward current was observed.

We also sought to determine whether application of $\mathrm{GnRH}$ alters the calcium current in mudpuppy olfactory neurons. Using a CsCl-based intracellular solution and an extracellular solution in which $\mathrm{BaCl}_{2}$ had been substituted for $\mathrm{CaCl}_{2}$ and $1 \mu \mathrm{M}$ TTX had been added, we were able to record from two neurons from two different animals. In these cells, we did not observe any changes in the magnitude or kinetics of the barium current after at least $15 \mathrm{~min}$ of exposure to $10 \mu \mathrm{M} \mathrm{GnRH}$.

\section{Responsiveness to GnRH may be seasonal, but is not sexually dimorphic}

The cells of the terminal nerve extend processes anteriorly to the nasal cavity and posteriorly to the hypothalamic/preoptic area. Developmentally, these cells are closely associated with GnRHcontaining cells of the hypothalamus that are involved in controlling the release of luteinizing hormone and follicle-stimulating hormone (Schwanzel-Fukuda et al., 1985; Northcutt and Muske, 1994). We therefore examined our data to determine whether the effect of GnRH on the inward current of olfactory receptor cells varies with the sex of the animal or with the season during which the recording was made.

We found that the probability of observing a response to $10 \mu \mathrm{M}$ GnRH was higher during the winter and spring than during the summer months. From June through August, 4 of 12 cells (33.3\%) from eight different animals responded to $\mathrm{GnRH}$ with an increase in the magnitude of the inward current, compared with 25 of 37 cells $(67.6 \%)$ from 15 different animals that responded to GnRH during the period from December through May. Although the higher percentage of cells responding during the winter and spring does not quite reach statistical significance (Fisher's exact test, one-tailed, $p=0.057$ ), this seasonal difference represents an intriguing phenomenon deserving of further study.

In contrast, the effect of GnRH on olfactory receptor cells does not appear to be sexually dimorphic, regardless of season. Although we did not record the sex of every animal that served as a subject, we obtained recordings from cells from nine adult males and six adult females. Among male mudpuppies, 12 of 21 cells (57\%) responded to $10 \mu \mathrm{M}$ GnRH with a sustained increase in the inward current, and 9 of 13 cells $(69 \%)$ from females responded similarly. This difference is not significant (Fisher's exact test, $p>$ $0.7)$. When only data from the winter and spring are included in the analysis, the proportion of cells that responded to $10 \mu \mathrm{M}$ GnRH is identical between males and females: six of nine cells (66.7\%) from four different males responded to $\mathrm{GnRH}$, as did 8 of 12 cells $(66.7 \%)$ from five different females. The increase in magnitude of the inward current did not differ significantly between males and females, regardless of whether data from all cells or only from responders are included in the analysis. For example, among 11 cells from eight different animals that responded to 10 $\mu \mathrm{M}$ GnRH, the maximum increase in the inward current in GnRH does not differ between males and females $\left(t_{(9)}=-0.247\right.$, $p>0.8)$.

\section{DISCUSSION}

GnRH exerts various effects on the nervous system. Its most prominent role is in the release of gonadotropin hormones from the anterior pituitary; accordingly, cellular effects of GnRH have been studied most thoroughly in gonadotrope cells. In gonadotrope cells from rats and sheep, GnRH causes hyperpolarization of the membrane potential, followed by a period in which the membrane potential oscillates because of rhythmic release of calcium from intracellular stores. Increase in intracellular calcium causes hormone release and stimulates a hyperpolarizing calcium-dependent potassium current (Tse and Hille, 1992; Heyward et al., 1995), which releases sodium and calcium channels from the inactivated state, leading to bursts of action potentials (Heyward et al., 1993; Tse and Hille, 1993). Stimulation with GnRH leads to rapid influx of calcium in gonadotrope cells from goldfish and humans (Jobin and Chang, 1992; Prevarskaya et al., 1994). In contrast, GnRH reduces the magnitude and slows the 
activation kinetics of calcium channels in bullfrog lumbar sympathetic ganglion cells (Elmslie et al., 1990; Boland and Bean, 1993).

In mudpuppies, we observed the presence of GnRHimmunoreactive terminal nerve fibers just below the olfactory epithelium, as has been reported in all jawed vertebrates examined thus far (Eisthen and Northcutt, 1996). The presence of these fibers in proximity to the olfactory epithelium suggests that they may be involved in olfactory function. Hormonal manipulations that decrease GnRH release, such as administration of melatonin (Wirsig-Wiechmann, 1993b) or estrogen (WirsigWiechmann and Lee, 1999), significantly increase the GnRH content of terminal nerve fibers, suggesting that these fibers normally release GnRH into the olfactory mucosa. We therefore hypothesized that GnRH may act as a modulator of olfactory receptor cell activity.

In olfactory receptor cells from adult mudpuppies, we found that bath application of $0.5-50 \mu \mathrm{M}$ GnRH increases the magnitude of a TTX-sensitive, voltage-activated inward current with features of the sodium current that underlies action potentials. In addition, GnRH appeared to alter the activity of an outward current, possibly a calcium-dependent potassium current. These effects do not resemble odorant responses. Odorant transduction involves activation of two distinct second-messenger pathways that produce various effects, including the opening of nonselective cation channels and several types of chloride channels (for review, see Schild and Restrepo, 1998). Although a broad array of odorant effects have been discovered thus far, odorants have not been shown to alter the magnitude of TTX-sensitive sodium currents. Furthermore, the time course of the response that we observed is not consistent with an odorant effect. In isolated olfactory receptor cells from mudpuppies, odorant responses occur within $200 \mathrm{msec}$, and the cells begin to adapt or desensitize to the presence of odorants within $10 \mathrm{sec}$ (Dionne, 1992). Any single odorant generally elicits a response from a minority of cells; for example, taurine, a potent odorant for mudpuppies, elicits responses from $24 \%$ of olfactory receptor cells when tested at 10-100 $\mu \mathrm{M}$ (Dubin and Dionne, 1993). In our experiments, the magnitude of the sodium current was increased in $59 \%$ of cells exposed to $10 \mu \mathrm{M}$ GnRH. Finally, in mudpuppy olfactory neurons, odorant responses disappear within a few seconds in normal whole-cell recordings, presumably because of washout of the intracellular components involved in odorant transduction (Dionne, 1992). In contrast, we were able to use whole-cell recording to examine effects of $\mathrm{GnRH}$ on voltage-activated currents over a period of $20-120 \mathrm{~min}$ in a total of 72 cells and did not encounter problems with washout in any cell. Taken together, our results indicate that GnRH does not act as an odorant, but instead is serving as a modulator of olfactory receptor cell activity.

This conclusion contrasts with that reached by Andersen and Døving (1991), who found that application of GnRH to the olfactory epithelium of rainbow trout (Oncorhynchus mykiss) elicited trans-epithelial voltage responses recorded as an electroolfactogram (EOG). Because EOG responses are thought to be summed generator potentials (Ottoson, 1956), the authors concluded that GnRH acts as an odorant in rainbow trout. However, more recent evidence suggests that Andersen and Døving's result may have been caused by contamination (K. B. Døving, personal communication), and GnRH does not elicit EOG responses in tiger salamanders (W. L. Silver and C. R. Wirsig-Wiechmann, unpublished observations).

Our results suggest the intriguing possibility that GnRH from the terminal nerve alters the excitability of olfactory receptor cells, possibly causing the cells to respond more readily and more vigorously to odorants. To test this idea directly, we attempted to use current-clamp recording to determine whether $\mathrm{GnRH}$ altered excitability of olfactory receptor cells. As is typical of olfactory receptor cells, we found that the cells did not have a stable resting potential; the resting potential of most cells drifted unpredictably between about -80 and $-20 \mathrm{mV}$ over the course of several minutes, obscuring our ability to interpret the results of GnRH application. However, other recording methods, such as the use of calcium imaging, could prove useful in determining whether GnRH enhances responsivity to odorants.

The response of olfactory receptor cells to GnRH appears to be seasonal, for GnRH was more likely to enhance the sodium current when recordings were conducted during the winter and spring than during the summer. Perhaps the terminal nerve acts to increase sensitivity to odorants during the breeding season. The animals used in our experiments were wild-caught in Wisconsin and Minnesota, where mudpuppies court and mate from October through April or May. The sexes then separate, and females lay eggs and guard the nest through the summer (Petranka, 1998). Because the terminal nerve appears to be activated during mating behavior (Propper and Moore, 1991), it may serve to sensitize the olfactory system to pheromones or other odorants that are critical for reproductive success. It would be particularly interesting to determine whether other terminal nerve-derived compounds, such as FMRFamide or acetylcholine, modulate activity of olfactory receptor cells in a seasonal manner.

GnRH may modulate activity of olfactory receptor cells at lower concentrations than were tested in this study. In most of our experiments, we explored the effects of exposure to $10 \mu \mathrm{M} \mathrm{GnRH}$ and tested lower concentrations on relatively small numbers of cells. We obtained a response at the lowest concentration tested, $0.5 \mu \mathrm{M}$, and olfactory receptor cells may respond to still lower concentrations. The concentration of GnRH that reaches olfactory receptor cells under normal physiological conditions is not known, nor can it reasonably be estimated at present. Experiments with tiger salamanders suggest that GnRH reaches the surface of the olfactory epithelium via secretion from nasal glands, for Bowman's glands display GnRH immunoreactivity (Wirsig-Wiechmann and Matsumoto, 1999). Attempts to analyze levels of GnRH by mass spectrometry and radioimmunoassay have indicated that GnRH levels in the mucus are below the nanomolar level of detection (C. R. Wirsig-Wiechmann, unpublished observations). However, secretion of GnRH into the mucus may be seasonally controlled and/or require specific sensory stimuli, rendering consistent detection difficult.

The activity of vertebrate olfactory receptor cells may be modulated by compounds from various sources in addition to the terminal nerve. Adrenergic autonomic fibers innervate the olfactory epithelium (Zielinski et al., 1989a), and adrenaline enhances odorant sensitivity as measured with EOG recordings (Arechiga and Alcocer-Cuaron, 1969). Recently, the mechanisms of this modulation were studied in newts (Cynops pyrrhogaster), in which adrenaline was found to increase the magnitude and alter the kinetics of a TTX-sensitive sodium current and to decrease the magnitude of a T-type calcium current, narrowing the dynamic range of the olfactory receptor neurons (Kawai et al., 1999). Stimulation of the trigeminal nerve in rats increases levels of catecholamines, including dopamine, in nasal mucus (Lucero and Squires, 1998), and dopamine increases the magnitude and shifts the voltage-dependence of an inwardly rectifying hyperpolarization-activated current in rat olfactory receptor neurons (Vargas 
and Lucero, 1999). Cholinergic fibers from both the terminal nerve (Schwanzel-Fukuda et al., 1986; Wirsig and Getchell, 1986; Wirsig and Leonard, 1986; White and Meredith, 1995) and autonomic nerves (Zielinski et al., 1989b) innervate the nasal cavity, and the olfactory epithelium contains muscarinic receptors (Hedlund and Shepherd, 1983). The firing rate of frog olfactory receptor neurons is altered by application of acetylcholine (Bouvet et al., 1988) through interaction with an odorant transduction mechanism. Frings (1993) showed that the muscarinic agonist carbachol stimulates protein kinase $\mathrm{C}$, potentiating adenylyl cyclase activity and leading to an increase in firing rate. Substance P may increase excitatory responses of olfactory receptor neurons [Bouvet et al. (1988), but see Frings (1993)] and is present in the trigeminal nerve (Cuello et al., 1978; Zielinski et al., 1989a). Similarly, serotonin increases excitation of olfactory receptor neurons (Frings, 1993), although a potential source of serotonin in the nasal cavity has not yet been identified. Thus, the sensitivity of olfactory receptor neurons appears to be modulated by compounds from diverse sources, including autonomic, trigeminal, and terminal nerves. Furthermore, our data suggest that this modulation may change dynamically depending on the animal's reproductive condition or behavioral context.

\section{REFERENCES}

Andersen O, Døving KB (1991) Gonadotropin releasing hormone $(\mathrm{GnRH})$ : a novel olfactory stimulant in fish. NeuroReport 2:458-460.

Arechiga H, Alcocer-Cuaron C (1969) Adrenergic effects on the electroolfactogram. Exp Med Surg 27:384-394.

Bigiani A, Roper SD (1995) Estimation of the junctional resistance between electrically coupled receptor cells in Necturus taste buds. J Gen Physiol 106:705-725.

Boland LM, Bean BP (1993) Modulation of N-type calcium channels in bullfrog sympathetic neurons by luteinizing hormone-releasing hormone: kinetics and voltage dependence. J Neurosci 13:516-533.

Bouvet JF, Delaleu JC, Holley A (1988) The activity of olfactory receptor cells is affected by acetylcholine and substance P. Neurosci Res 5:214-223.

Bullock TH, Northcutt RG (1984) Nervus terminalis in dogfish (Squalus acanthias, Elasmobranchii) carries tonic efferent impulses. Neurosci Lett 44:155-160.

Chiba A, Honma Y (1992) Distribution of neuropeptide Y-like immunoreactivity in the brain and hypophysis of the cloudy dogfish, Scyliorhinus torazame. Cell Tissue Res 268:453-461.

Cuello AC, Del Fiacco M, Paxinos G (1978) The central and peripheral ends of the substance P-containing sensory neurones in the rat trigeminal system. Brain Res 152:499-509.

Demski LS (1993) Terminal nerve complex. Acta Anatomica 148:81-95.

Demski LS, Northcutt RG (1983) The terminal nerve: a new chemosensory system in vertebrates? Science 220:435-437.

Dionne VE (1988) Membrane conductance mechanisms of dissociated cells from the olfactory epithelium of the mudpuppy, Necturus maculosus. In: Olfaction and taste IX: from reception to perception, Vol 510 (Roper S, Atema J, eds), pp 258-259. New York: New York Academy of Sciences.

Dionne VE (1992) Chemosensory responses in isolated olfactory receptor neurons from Necturus maculosus. J Gen Physiol 99:415-433.

Dubin AE, Dionne VE (1993) Modulation of $\mathrm{Cl}^{-}, \mathrm{K}^{+}$, and nonselective cation conductances by taurine in olfactory receptor neurons of the mudpuppy Necturus maculosus. J Gen Physiol 101:469-485.

Eisthen HL, Northcutt RG (1996) Silver lampreys (Ichthyomyzon unicuspis) lack a gonadotropin-releasing hormone- and FMRF amideimmunoreactive terminal nerve. J Comp Neurol 370:159-172.

Elmslie KS, Zhou W, Jones SW (1990) LHRH and GTP-gamma-S modify calcium current activation in bullfrog sympathetic neurons. Neuron 5:75-80.

Frings S (1993) Protein kinase C sensitizes olfactory adenylate cyclase. J Gen Physiol 101:183-205.

Fritsch G (1878) Untersuchungen über den feineren Bau des Fischgehirns mit besonderer Berücksichtigung der Homologien bei anderen Wirbelthierklassen. Berlin: Verlag der Gutmann'schen Buchhandlung.
Fujita I, Sorenson PW, Stacey NE, Hara TJ (1991) The olfactory system, not the terminal nerve, functions as the primary chemosensory pathway mediating responses to sex pheromones in the male goldfish. Brain Behav Evol 38:313-321.

Hedlund B, Shepherd GM (1983) Biochemical studies of muscarine receptors in the salamander olfactory epithelium. FEBS Lett 162:428-431.

Heyward PM, Chen C, Clarke IJ (1993) Gonadotropin-releasing hormone modifies action potential generation in sheep pars distalis gonadotropes. Neuroendocrinology 58:646-654.

Heyward PM, Chen C, Clarke IJ (1995) Inward membrane currents and electrophysiological responses to $\mathrm{GnRH}$ in ovine gonadotropes. Neuroendocrinology 61:609-621.

Iela L, Powell JFF, Sherwood NM, D’Aniello B, Rastogi RK, Bagnara JT (1996) Reproduction in the Mexican leaf frog, Pachymedusa dacnicolor. VI. Presence and distribution of multiple GnRH forms in the brain. Gen Comp Endocrinol 103:235-243.

Jobin RM, Chang JP (1992) Actions of two native GnRHs and protein kinase $\mathrm{C}$ modulators on goldfish pituitary cells. Studies on intracellular calcium levels and gonadotropin release. Cell Calcium 13:531-540.

Kawai F, Kurahashi T, Kaneko A (1999) Adrenaline enhances odorant contrast by modulating signal encoding in olfactory receptor cells. Nat Neurosci 2:133-138.

Lucero MT, Squires A (1998) Catecholamine concentrations in rat nasal mucus are modulated by trigeminal stimulation of the nasal cavity. Brain Res 807:234-236.

Murakami S, Kikuyama S, Arai Y (1992) The origin of the luteinizing hormone-releasing hormone (LHRH) neurons in newts (Cynops pyrrhogaster): the effect of olfactory placode ablation. Cell Tissue Res 269:21-27.

Northcutt RG, Muske LE (1994) Multiple embryonic origins of gonadotropin-releasing hormone $(\mathrm{GnRH})$ immunoreactive neurons. Dev Brain Res 78:279-290.

Oka Y, Matsushima T (1993) Gonadotropin-releasing hormone $(\mathrm{GnRH})$-immunoreactive terminal nerve cells have intrinsic rhythmicity and project widely in the brain. J Neurosci 13:2161-2176.

Ottoson D (1956) Analysis of the electrical activity of the olfactory epithelium. Acta Physiol Scand 35:1-83.

Petranka JW (1998) Salamanders of the United States and Canada. Washington, DC: Smithsonian Institution.

Pinkus F (1894) Über einen noch nicht beschriebenen Hirnnerven des Protopterus annectens. Anat Anz 9:562-566.

Pinkus F (1895) Die Hirnnerven des Protopterus annectens. Morph Arb 4:275-346.

Prevarskaya N, Skryma R, Vacher P, Bresson-Bepoldin L, Odessa MF, Rivel J, San Galli F, Guerin J, Dufy-Barbe L (1994) Gonadotropinreleasing hormone induced $\mathrm{Ca}^{2+}$ influx in nonsecreting pituitary adenoma cells: role of voltage-dependent $\mathrm{Ca}^{2+}$ channels and protein kinase C. Mol Cell Neurosci 5:699-708.

Propper CR, Moore FL (1991) Effects of courtship on brain gonadotropin hormone-releasing hormone and plasma steroid concentrations in a female amphibian (Taricha granulosa). Gen Comp Endocrinol 81:304-312.

Rossi A, Basile A, Palombi F (1972) Speculations on the function of the nervus terminalis in teleosts. Riv Biol 65:385-409.

Schild D, Restrepo D (1998) Transduction mechanisms in vertebrate olfactory receptor cells. Physiol Rev 78:429-466.

Schwanzel-Fukuda M, Morrell JI, Pfaff DW (1985) Ontogenesis of neurons producing luteinizing hormone-releasing hormone $(\mathrm{LHRH})$ in the nervus terminalis of the rat. J Comp Neurol 238:348-364.

Schwanzel-Fukuda M, Morrell JI, Pfaff DW (1986) Localization of choline acetyltransferase and vasoactive intestinal polypeptide-like immunoreactivity in the nervus terminalis of the fetal and neonatal rats. Peptides 7:899-906.

Sherwood NM, Zoeller RT, Moore FL (1986) Multiple forms of gonadotropin-releasing hormone in amphibian brains. Gen Comp Endocrinol 61:313-322.

Tse A, Hille B (1992) GnRH-induced $\mathrm{Ca}^{2+}$ oscillations and rhythmic hyperpolarizations of pituitary gonadotropes. Science 255:462-464.

Tse A, Hille B (1993) Role of voltage-gated $\mathrm{Na}^{+}$and $\mathrm{Ca}^{2+}$ channels in gonadotropin-releasing hormone-induced membrane potential changes in identified rat gonadotropes. Endocrinology 132:1475-1481.

Vallarino M, Tranchand-Bune D, Thoumas JL, Masini MA, Conlon JM, Fournier A, Pelletier G, Vaudry H (1995) Neuropeptide tyrosine in the brain of the African lungfish, Protopterus annectens: immunohisto- 
chemical localization and biochemical characterization. J Comp Neurol 356:537-551.

Vargas G, Lucero MT (1999) Dopamine modulates inwardly rectifying hyperpolarization-activated current $\left(\mathrm{I}_{\mathrm{h}}\right)$ in cultured rat olfactory receptor neurons. J Neurophysiol 81:149-158.

Walker SE, Stell WK (1986) Gonadotropin-releasing hormone (GnRF), molluscan cardioexcitatory peptide (FMRFamide), enkephalin and related neuropeptides affect goldfish retinal ganglion cell activity. Brain Res 384:262-273.

White J, Meredith M (1987) The nervus terminalis of the shark: the effect of efferent impulses on ganglion cell activity. Brain Res 400:159-164.

White J, Meredith M (1995) Nervus terminalis ganglion of the bonnethead shark (Sphyrna tiburo): evidence for cholinergic and catecholamingeric influence on two cell types distinguished by peptide immunocytochemistry. J Comp Neurol 351:385-403.

Wirsig CR, Getchell TV (1986) Amphibian terminal nerve: distribution revealed by LHRH and AChE markers. Brain Res 385:1-21.

Wirsig CR, Leonard CM (1986) Acetylcholinesterase and luteinizing hormone-releasing hormone distinguish separate populations of terminal nerve neurons. Neuroscience 19:719-740.

Wirsig CR, Leonard CM (1987) Terminal nerve damage impairs mating behavior of the male hamster. Brain Res 417:293-303.

Wirsig-Wiechmann CR (1990) The nervus terminalis in the chick: a
FMRFamide-immunoreactive and AChE-positive nerve. Brain Res 523:175-179.

Wirsig-Wiechmann CR (1993a) Nervus terminalis lesions: I. No effect on pheromonally induced testosterone surges in the male hamster. Physiol Behav 53:251-255.

Wirsig-Wiechmann CR (1993b) Peripheral projections of nervus terminalis LHRH-containing neurons in the tiger salamander, Ambystoma tigrinum. Cell Tissue Res 273:31-40.

Wirsig-Wiechmann CR, Jennes L (1993) Gonadotropin-releasing hormone agonist binding in tiger salamander nasal cavity. Neurosci Lett 160:201-204.

Wirsig-Wiechmann CR, Lee CE (1999) Estrogen regulates gonadotropin-releasing hormone in the nervus terminalis of Xenopus laevis. Gen Comp Endocrinol 115:301-308.

Wirsig-Wiechmann CR, Matsumoto H (1999) Bowman's glands and nasal mucus contain gonadotropin-releasing hormone. Chem Senses 24:557.

Zielinski BS, Getchell ML, Getchell TV (1989a) Ultrastructural evidence for peptidergic innervation of the apical region of frog olfactory epithelium. Brain Res 492:361-365.

Zielinski BS, Getchell ML, Wenokur RL, Getchell TV (1989b) Ultrastructural localization and identification of adrenergic and cholinergic nerve terminals in the olfactory mucosa. Anat Rec 225:232-245. 